\title{
Acid-Base Properties of Aqueous Suspensions of Homoionic Sepiolite and Palygorskite
}

\author{
Silvia G. Acebal* , Leticia I. Vico \\ Departamento de Química, Universidad Nacional del Sur, Bahía Blanca, Argentina \\ Email: *sacebal@criba.edu.ar
}

How to cite this paper: Acebal, S.G. and Vico, L.I. (2017) Acid-Base Properties of Aqueous Suspensions of Homoionic Sepiolite and Palygorskite. Natural Resources, 8, 432-444.

https://doi.org/10.4236/nr.2017.86028

Received: March 29, 2017

Accepted: June 19, 2017

Published: June 23, 2017

Copyright $\odot 2017$ by authors and Scientific Research Publishing Inc. This work is licensed under the Creative Commons Attribution International License (CC BY 4.0).

http://creativecommons.org/licenses/by/4.0/

c) (i) Open Access

\begin{abstract}
Acid-base properties of $\mathrm{Na}$-sepiolite and Na-palygorskite were studied by potentiometric titrations at $298 \mathrm{~K}$ and two ionic strength $\mathrm{I}=0.1$ and $\mathrm{I}=0.002$. Intrinsic constants of deprotonation were calculated by two different methods: a) Stumm method, by extrapolating to zero the function that relates surface charge with the logarithms of apparent acidity constants and b) with MINTEQ program by minimizing the differences between surface $\mathrm{H}^{+}$concentration data and the values obtained from deprotonation constants proposed according to the Diffuse-Double-Layer Model (DDLM). Hydroxyl groups located at the broken edges of these fibrous clay minerals $(\mathrm{SOH})$ and permanent charge sites $\left(\mathrm{X}^{-}\right)$were considered as reactive sites. The determined values of the acid-base constants for Na-sepiolite and Na-palygorskite were intermediate between those for $\mathrm{SiO}_{2}$ and $\gamma-\mathrm{Al}_{2} \mathrm{O}_{3}$, which is in agreement with minerals that contain moderately strong-acidity and weak-acidity surface groups. The $\mathrm{SOH}$ groups showed an initial increase (after $\mathrm{SOH}_{2}{ }^{+}$deprotonation), forming a plateau with a slight decrease at high $\mathrm{pH}$ values (8-9) due to the formation of $\mathrm{SO}^{-}$sites. $\mathrm{X}^{-}$sites adsorbed $\mathrm{H}^{+}, \mathrm{Na}^{+}$or $\mathrm{Mg}^{2+}$ ions.
\end{abstract}

\section{Keywords}

Fibrous Clay Minerals, Sorption Properties, Surface Speciation

\section{Introduction}

Sepiolite and palygorskite are classified as phyllosilicates, because according to the definition of this mineral group [1], they contain a continuous two-dimensional tetrahedral sheet. However, they differ from the other layer silicates in lacking continuous octahedral sheets (Figure 1).

Consequently, ribbons containing $\mathrm{MgO}_{6}\left(\mathrm{AlO}_{6}\right)$ octahedral groups and rectangular channels run parallel across to the octahedral sheet [4], the width of the ribbons and the channels differing a little in sepiolite and in palygorskite. In pa- 


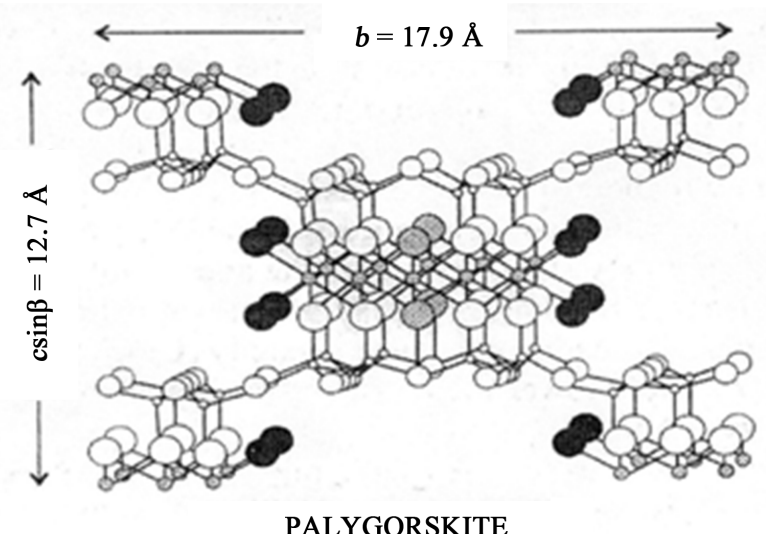

(a)

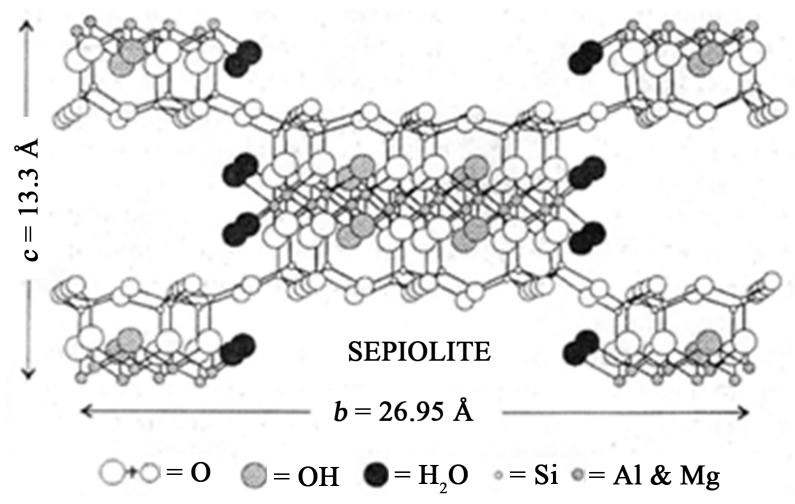

(b)

Figure 1. (a) Schematic structure of palygorskite [2]; (b) Sepiolite structure [3]. Figure adapted from [4], 1988, and [5].

lygorskite, $\mathrm{Mg}^{2+}$ occupies only $29 \%$ to $76 \%$ of the octahedral sites while in sepiolite, it fills $90 \%$ to $100 \%$ of these sites [6]. The structure of these clay minerals includes three types of active adsorption sites: basal $\mathrm{O}$ atoms on the tetrahedral sheets of the ribbons, $\mathrm{H}_{2} \mathrm{O}$ molecules coordinated to $\mathrm{Mg}^{2+}$ at the edges of structural ribbons and $\mathrm{SiOH}$ groups associated in large number with terminal Si tetrahedral at the external surfaces. Other structural surface groups such as $\mathrm{Al}_{2}-\mathrm{OH}, \mathrm{Al}-\mathrm{OH}$, and $\mathrm{Mg}-\mathrm{OH}$ have been detected in palygorskite [7]. It is likely that some other hydroxyl groups may appear on the external surface of the clay minerals where broken bonds give rise to incomplete tetrahedral or octahedral structural units. In addition, as a result of some isomorphous replacement in the tetrahedral sheet, such as $\mathrm{Al}^{3+}$ for $\mathrm{Si}^{4+}$, negatively charged adsorption sites are observed. This structural charge must be balanced by cations at or near the mineral surface. The spatial distribution of these exchangeable "counterions" in the vicinity of the surface greatly affects the colloidal behavior of clay minerals.

Sepiolite and palygorskite have been used for sorbent purposes since 1930. They were used to adsorb grease, oil, water, and other undesirable substances spilled on the floor of factories. Adsorbent granules are also used as pesticide carriers and bleaching agents for mineral and vegetable oils, butter, and wine. 
The acid-base properties of the surface may have a relevant role on these adsorption processes. The interaction of clay mineral surfaces with $\mathrm{H}^{+}$and $\mathrm{OH}^{-}$must be known when surface models are used to explain the adsorption mechanism of different chemical species. A great deal of effort has been expended in developing models to describe the clay interfacial region. Some researchers have assessed the adsorption of $\mathrm{H}^{+}$and different metallic ions on hydrous oxides, soils, soil fractions and clay minerals [8]-[19]. In these works, a wide variety of thermodynamic models describing the adsorption of chemical species to different surfaces have been developed, including the constant capacitance model (CCM), the diffuse-double-layer model (DDLM), the triple-layer model (TLM), and the multisite complexation model (MUSIC). The first group (CCM, DDLM and TLM), also termed two-pk models, treats the surfaces on a single-site basis. These models have been successfully used in describing acid-base behavior in smectitic clay minerals. However, only a few works deal with fibrous clay minerals as sepiolite and/or palygorskite whose edge surfaces also present reactive $\mathrm{Mg}-\mathrm{OH}$ groups. The aim of this study was to explain acid-base properties of Na-sepiolite and Na-palygorskite by modeling adsorption processes based on the existence of different structural sites using the DDLM. The DDLM model was chosen because of the simplicity of the application considering the weakness of clay mineral samples.

\section{Materials and Methods}

\subsection{Clay Minerals}

A sepiolite from Vallecas (Madrid) and a palygorskite from Torrejón el Rubio (Cáceres), Spain, were used as adsorbents in this study. The $<2 \mu \mathrm{m}$ fraction was saturated with $\mathrm{Na}^{+}$by repeated washing with $5 \times 10^{-1} \mathrm{M} \mathrm{NaCl}$ solution. Excess salt was removed by several washings with bidistilled water until $\mathrm{Cl}^{-}$detection using $0.5 \mathrm{M} \mathrm{AgNO}_{3}$ became negative. Then, the air-dried Na-clay mineral was gently ground in a porcelain mortar.

Specific surface area was determined by $\mathrm{N}_{2}$ adsorption at the temperature of liquid $\mathrm{N}_{2}$, after degassing the samples. The classical BET equation was used for external surface area calculation. Total surface area was determined by ethylene glycol monoethyl ether (EGME) method [20].

Cation exchange capacity (CEC) of the samples was obtained by saturation with a buffered-pH $71 \mathrm{M} \mathrm{NH}_{4}$-acetate [21].

$\mathrm{X}$-Ray diffraction (XRD) was performed using $\mathrm{CuK \alpha}(1.5046 \AA)$ radiation (35 $\mathrm{kV}, 15 \mathrm{~mA}$ ) on a Rigaku Geiger Flex, DMax III-C horizontal goniometer equipped with a microcomputer system with graphite monochromator.

IR spectra were obtained on a Nicolet FTIR, Nexus 470 spectrophotometer using an Avatar Diffuse Reflectance accessory for the solid dispersion as $\mathrm{KBr}$ (1.35 mg of sample:295 mg of $\mathrm{KBr}$ ).

Representative major and trace elements for the samples were chemically determined by acid dissolution for total elemental analysis [22]. 


\subsection{Surface Charge Determinations}

Proton surface-charge determinations were performed by potentiometric titration of the suspensions with $0.1 \mathrm{M} \mathrm{HNO}_{3}$ and $0.1 \mathrm{M} \mathrm{NaOH}$ solutions at $298 \mathrm{~K}$, under $\mathrm{N}_{2}$ atmosphere for displacing the dissolved $\mathrm{CO}_{2}$.

The suspensions were prepared in $0.1 \mathrm{M}$ or $0.001 \mathrm{M} \mathrm{NaNO}_{3}$ solutions. In the first case the ionic strength remained constant during titrations, but in the second case it varied in the range 0.001 to 0.003 due to acid or base additions. Then, in this study, the lower ionic strength will be considered to be $\mathrm{I}=0.002$. The suspensions were shaken for 5 minutes, and $\mathrm{pH}$ was measured at oneminute intervals after the addition of acid (or base) to reach a new titration point. The initial $\mathrm{pH}$ was 8.2 for Na-sepiolite, and 9.0 for Na-palygorskite. When potentiometric titration was ended the suspensions were centrifuged, and free $\mathrm{Mg}^{2+}$ concentration was determined in the supernatant solutions by Atomic $\mathrm{Ab}$ sorption Spectrometry using a GBC 932 B computerized spectrometer. Potentiometric titrations in the absence of the clay minerals (blanks) were also performed. A Cole-Parmer pHmeter was used. In all the experiments, the concentration of adsorbent in the solution was $10 \mathrm{~g} \mathrm{~L}^{-1}$. All experiments were carried out in duplicate.

\subsection{Chemical Equilibria}

Hydroxyl groups located at the broken edges of these fibrous clay minerals and permanent charge sites will be called $\mathrm{SOH}$ groups and $\mathrm{X}^{-}$sites respectively. They are assumed to participate in $\mathrm{pH}$-dependent protonation-deprotonation reactions and cation adsorption reactions as follows [23]:

$$
\begin{aligned}
& \mathrm{SOH}_{2}^{+} \Leftrightarrow \mathrm{SOH}+\mathrm{H}^{+} \quad k_{\text {alapp }} \\
& k_{\text {alapp }}=\frac{[\mathrm{SOH}]\left[\mathrm{H}^{+}\right]}{\left[\mathrm{SOH}_{2}^{+}\right]} \\
& \mathrm{SOH} \Leftrightarrow \mathrm{SO}^{-}+\mathrm{H}^{+} \quad k_{\text {a2app }} \\
& k_{\text {a2app }}=\frac{\left[\mathrm{SO}^{-}\right]\left[\mathrm{H}^{+}\right]}{[\mathrm{SOH}]} \\
& \mathrm{X}^{-}+\mathrm{H}^{+} \Leftrightarrow \mathrm{XH} \quad k_{\mathrm{XH}} \\
& \mathrm{X}^{-}+\mathrm{Na}^{+} \Leftrightarrow \mathrm{XNa} \quad k_{\mathrm{XNa}} \\
& 2 \mathrm{X}^{-}+\mathrm{Mg}^{2+} \Leftrightarrow \mathrm{X}_{2} \mathrm{Mg} \quad k_{\mathrm{X}_{2} \mathrm{Mg}}
\end{aligned}
$$

where $k_{\mathrm{XH}}, k_{\mathrm{XNa}}$ and $k_{\mathrm{X}_{2} \mathrm{Mg}}$ are $\mathrm{X}^{-}$permanent charge site constants. Eq 5 takes into account the possible re-adsorption of free $\mathrm{Mg}^{2+}$ released during the treatment from octahedral sheet.

In eqs 1 and $2, k_{\text {alapp }}$ and $k_{\text {azapp }}$ represent "conditional or apparent acidity" equilibrium constants. The conditional or apparent equilibrium constants can be experimentally measured and will be equal to the thermodynamic constants $(K)$ in an ideal behavior situation. Corresponding to the equilibria in both equations 
are expressions of the law of mass action in system subject to an electric field, which can be written

$$
\begin{aligned}
& k_{a 1 \mathrm{int}}=\exp \left(-\frac{F \psi}{R T}\right) \frac{[\mathrm{SOH}]\left[\mathrm{H}^{+}\right]}{\left[\mathrm{SOH}_{2}^{+}\right]} \\
& k_{a 2 \text { int }}=\exp \left(-\frac{F \psi}{R T}\right) \frac{\left[\mathrm{SO}^{-}\right]\left[\mathrm{H}^{+}\right]}{[\mathrm{SOH}]}
\end{aligned}
$$

$k_{\text {alint }}$ and $k_{\text {a2int }}$ represent intrinsic acidity equilibrium constants,

[ ] is molar concentration $\left(\mathrm{mol} \mathrm{L}^{-1}\right)$,

$\psi$ is the surface potential,

$F$ is Faraday's constant.

$R$ is universal gas constant,

$T$ is temperature $(\mathrm{K})$.

\subsection{Calculation Procedures}

Surface charge data were analyzed in two different ways:

1) Stumm method was used to obtain the two unique intrinsic acidity constants (Equations (6) and (7)), which determine acid-base characteristics of the surface.

This method extrapolates to zero the function that relates surface charge (Q) with the logarithms of "conditional or apparent acidity" constants $k_{\text {alapp }}$ and $k_{\text {a2app }}[24]$.

Note that in Equations (1) and (2) $\left[\mathrm{H}^{+}\right]=10^{-\mathrm{pH}}$, and in the acid zone,

$$
[\mathrm{SOH}]=\text { total sites }=(\text { total surface sites })-\left[\mathrm{SOH}_{2}^{+}\right]
$$

and in the basic zone,

$$
[\mathrm{SOH}]=\text { total sites }=(\text { total surface sites })-\left[\mathrm{SO}^{-}\right]
$$

Total surface sites were considered as the maximum $\mathrm{H}^{+}$or $\mathrm{OH}^{-}$adsorption of surface groups.

$$
\begin{aligned}
& {\left[\mathrm{SOH}_{2}^{+}\right]=\left(\left[\mathrm{HNO}_{3}\right] \text { added to suspension }\right)-\left(\left[\mathrm{HNO}_{3}\right] \text { added to blank }\right)} \\
& {\left[\mathrm{SO}^{-}\right]=([\mathrm{NaOH}] \text { added to suspension })-([\mathrm{NaOH}] \text { added to blank })}
\end{aligned}
$$

On the other hand, the charge due to interaction between $\mathrm{H}^{+}$and $\mathrm{OH}^{-}$ions and the surface groups is accessible from the titration curves based on charge balance as follows:

$$
C_{B}-C_{A}+\left[\mathrm{H}^{+}\right]-\left[\mathrm{OH}^{-}\right]=\left[\mathrm{SO}^{-}\right]-\left[\mathrm{SOH}_{2}^{+}\right]=-Q
$$

where $C_{B}$ and $C_{A}$ are the concentrations $\left(\mathrm{mol} \mathrm{L}^{-1}\right)$ of added strong base and added strong acid, respectively.

With reference to Equations (10) and (11)

$$
\begin{aligned}
& {\left[\mathrm{SOH}_{2}^{+}\right] \sim Q \text { in the acid zone }} \\
& {\left[\mathrm{SO}^{-}\right] \sim Q \text { in the basic zone }}
\end{aligned}
$$


Finally, a plot of the negative logarithm of $k_{\text {alapp }}$ and $k_{\text {azapp }}$ versus $Q$ will yield the negative logarithm of the intrinsic equilibrium constant ( $k_{\mathrm{alint}}$ and $k_{\mathrm{a} 2 \mathrm{int}}$ ), upon linear extrapolation to zero surface charge.

2) MINTEQ program [25] allowed the calculation of $k_{\text {alapp }}, k_{\text {azapp }}, k_{\mathrm{XH}}, k_{\mathrm{XNa}}$ and $k_{\mathrm{X}_{2} \mathrm{Mg}}$ (Equations (1)-(5)) by minimizing the differences between experimental surface $\left[\mathrm{H}^{+}\right]$and the data set obtained by the program from deprotonation constants proposed.

To account for these experimental results the diffuse-double-layer model (DDLM, plane geometry, without counter-ion accumulation) with the option "fixed surface charge", which permit representation of $\mathrm{X}^{-}$sites surface reactions (Equations (3)-(5)) was used.

\section{Results and Discussion}

\subsection{Surface and Exchange Properties of Clay Minerals}

Some surface and exchange properties of the selected homoionic samples are reported in Table 1. BET specific areas were smaller than EGME areas since the first method is used to determine only the external surface area. The BET- $\mathrm{N}_{2}$ surface area of Na-sepiolite was found to be $251.5 \mathrm{~m}^{2} \mathrm{~g}^{-1}$ (at $-197^{\circ} \mathrm{C}$ ) and 478 $\mathrm{m}^{2} \mathrm{~g}^{-1}$ with EGME vapor adsorption $\left(\right.$ at $25^{\circ} \mathrm{C}$ ), assuming a molecular cross-sectional area of $52 \AA$, indicating a possible greater penetration of pores and channels by EGME vapor compared to $\mathrm{N}_{2}$ under these conditions. The same behavior was observed in Na-palygorskite (Table 1). Channel surfaces are also reported (see Table 1). CECs and specific surface area values obtained are in agreement with the reported values in the literature for reference minerals [6].

XRD patterns showed a highly pure sepiolite sample and a well-crystallized palygorskite sample containing some quartz as impurity. Sepiolite gave a strong XRD line at $12.12 \AA$ Á with moderate reflections at, 4.49, 4.29, 4.02, 3.74, 3.34, and 3.18 , and diffuse reflections at 7.5, and $5.04 \AA$. For palygorskite, a strong reflection occurred at $10.52 \AA$, and moderate reflections at 6.36 to $6.44,5.38$ to 5.42 , 4.46 to $4.49,4.24$ to $4.26,3.61$ to 3.69 , and $3.23 \AA$.

IR absorption spectra of both clay minerals permitted the vibration band assignments. Sepiolite showed stretching vibrations of structural $\mathrm{OH}$ in the edge silanol groups and in the octahedral sheet $\left(3685 \mathrm{~cm}^{-1}\right), \mathrm{OH}$-stretching bands of coordinated $\mathrm{H}_{2} \mathrm{O}\left(3619 ; 3561 \mathrm{~cm}^{-1}\right)$, adsorbed $\mathrm{H}_{2} \mathrm{O}$ stretching vibration (3371; $\left.3231 \mathrm{~cm}^{-1}\right)$, OH-bending vibration of coordinated $\mathrm{H}_{2} \mathrm{O}\left(1662 ; 1625 \mathrm{~cm}^{-1}\right)$, stretching vibration of Si-O in tetrahedral sheet $\left(1211 \mathrm{~cm}^{-1}\right)$, stretching vibration of

Table 1. Some characteristics of the fibrous clay minerals.

\begin{tabular}{|c|c|c|c|c|}
\hline \multirow{2}{*}{ Sample } & \multicolumn{2}{|c|}{ Specific Surface Area $\left(\mathrm{m}^{2} \mathrm{~g}^{-1}\right)$} & \multirow{2}{*}{$\begin{array}{c}\text { Cation Exchange } \\
\text { Capacity [21] } \\
\left(\mathrm{cmol}_{\mathrm{c}} \mathrm{kg}^{-1}\right) \text { CEC }\end{array}$} & \multirow{2}{*}{$\begin{array}{c}\text { Channel } \\
\text { Dimensions [6] }(\AA)\end{array}$} \\
\hline & BET & EGME [20] & & \\
\hline Na-Sepiolite & 251.5 & 478.0 & 26.6 & $3.7 \times 10.6$ \\
\hline Na-Palygorskite & 147.6 & 354.3 & 17.0 & $3.7 \times 6.4$ \\
\hline
\end{tabular}


Si-O-Si groups (bridges between alternating Al-Mg-silicate ribbons) (900 - 1000 $\mathrm{cm}^{-1}$ ) and Si-O-bending vibrations $\left(478 ; 466 \mathrm{~cm}^{-1}\right.$ ). In the same region (465$470 \mathrm{~cm}^{-1}$ ) would be overlapped Si-O-Mg vibration. For palygorskite stretching vibration of structural $\mathrm{OH}$ in edge $(\mathrm{Mg}, \mathrm{Al})-\mathrm{OH}$ groups $\left(3611 ; 3576 ; 3541 \mathrm{~cm}^{-1}\right)$, $\mathrm{OH}$-stretching bands of adsorbed $\mathrm{H}_{2} \mathrm{O}\left(3379 ; 3274 \mathrm{~cm}^{-1}\right)$, OH-bending vibration of coordinated $\mathrm{H}_{2} \mathrm{O}\left(1658 \mathrm{~cm}^{-1}\right)$, stretching vibration of Si-O in tetrahedral sheet (1188; 1122; 1091; 1029; $982 \mathrm{~cm}^{-1}$ ), stretching vibration of Si-O-Si groups (bridges between alternating $\mathrm{Al}-\mathrm{Mg}$-silicate ribbons) $\left(1188 \mathrm{~cm}^{-1}\right)$, Si-O-Al bending vibration $\left(513 \mathrm{~cm}^{-1}\right)$, Si-O bending vibration $\left(482 \mathrm{~cm}^{-1}\right)$, Si-O-Mg bending vibration $\left(450 \mathrm{~cm}^{-1}\right)$ were observed. These assignments are in agreement with the reported values in the literature for reference minerals [6]. Details of XRD patterns and IR spectra can be found in [26].

The approximately formula of the unit cell of the minerals was determined for sepiolite $\left[\mathrm{Na}_{0,025} \mathrm{Ca}_{0,088} \mathrm{~K}_{0,10} \mathrm{Mg}_{8,16} \mathrm{Si}_{11,27} \mathrm{Al}_{0,64} \mathrm{Fe}_{0,12} \mathrm{O}_{30}(\mathrm{OH})_{4}\left(\mathrm{H}_{2} \mathrm{O}\right)_{4}\right]$ and palygorskite $\left.\left[\mathrm{Na}_{0,22} \mathrm{Mg}_{2,53} \mathrm{Al}_{1,78} \mathrm{Si}_{7,88} \mathrm{Al}_{0,22} \mathrm{Fe}_{0,37} \mathrm{O}_{20}(\mathrm{OH})_{4}\left(\mathrm{H}_{2} \mathrm{O}\right)_{4}\right)\right]$. Some substitution of $\mathrm{Si}^{4+}$ by $\mathrm{Al}^{3+}$ and $\mathrm{Fe}^{3+}$ in the tetrahedral sheet was observed.

\subsection{Protonation-Deprotonation Equilibria}

Data providing proton adsorption on homoionic forms of sepiolite and palygorskite at $\mathrm{I}=0.1$ and $\mathrm{I}=0.002$ (titration points) are shown in Figure 2. However, it should be noted that these potentiometric titration curves take account of dissolution processes involving structural $\mathrm{Mg}^{2+}$ ions. Acid amount associated with $\mathrm{Mg}^{2+}$ dissolution was discounted from initial acid amount $\left(2 \mathrm{H}^{+}\right.$by $\mathrm{Mg}^{2+}$ released). To gain insight into the nature of proton adsorption and in order to confirm the relative position of the curve, i.e. to determine if protons adsorp-

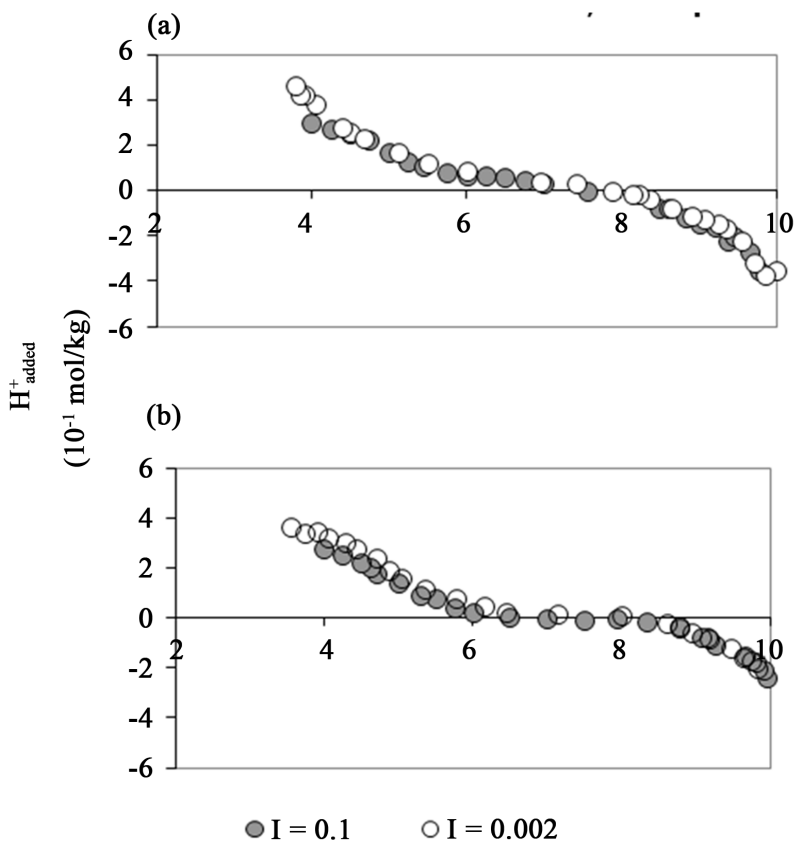

Figure 2. Proton adsorption on Na-sepiolite and Na-palygorskite in $\mathrm{NaNO}_{3}$ solution. Ionic strength (I) $=0.1$ and $\mathrm{I}=0.002$. (a) Na-sepiolite; (b) Na-palygorskite. 
tion increases or decreases with the increase of I; at different points of the titration curve on extreme $\mathrm{pH}$ values, some drops of $\mathrm{NaNO}_{3}$ saturated solution were added. These additions produced a decrease in $\mathrm{pH}$ values at $\mathrm{pH} 3$ and $\mathrm{pH} 10$. Then, it can be assumed that the titration curves run parallel one to the other, without crossing points, in both clay minerals. In this case, the behavior of $\mathrm{Na}$ sepiolite and Na-palygorskite is in agreement with the behavior of permanent charge phyllosilicates. At $\mathrm{I}=0.002$ some $\mathrm{Mg}^{2+}$ structural sites are released by dissolution, so these sites are able to capture $\mathrm{H}^{+}$.

\subsection{Deprotonation Equilibria Calculated According to Stumm Method}

Figure 3 shows Stumm's method of calculation for the intrinsic deprotonation constants and the values obtained for $\mathrm{k}_{\mathrm{alint}}$ and $\mathrm{k}_{\mathrm{azint}}$.

Intrinsic protonation-deprotonation (Stumm and DDLM) constants and $1 / 2$ $\left(\mathrm{pk}_{\mathrm{alint}}+\mathrm{pk}_{\mathrm{azint}}\right)$ values are listed in Table 2 .

The comparison between the deprotonation constants $\left(\mathrm{k}_{\mathrm{alint}}\right.$ and $\left.\mathrm{k}_{\mathrm{azin}}\right)$ of $\mathrm{SiO}_{2}$ greater than $\gamma-\mathrm{Al}_{2} \mathrm{O}_{3}$ constants highlighted the known fact that, $\mathrm{Si}-\mathrm{OH}$ groups in $\mathrm{SiO}_{2}$ are more acid than $\mathrm{Al}-\mathrm{OH}$ groups in $\gamma-\mathrm{Al}_{2} \mathrm{O}_{3}$ (see Table 2). The calculated values for $\mathrm{k}_{\mathrm{alint}}$ constants of $\mathrm{Na}$-sepiolite and $\mathrm{Na}$-palygorskite were intermediate between those for $\mathrm{SiO}_{2}$ and $\gamma-\mathrm{Al}_{2} \mathrm{O}_{3}$ according with minerals that con-

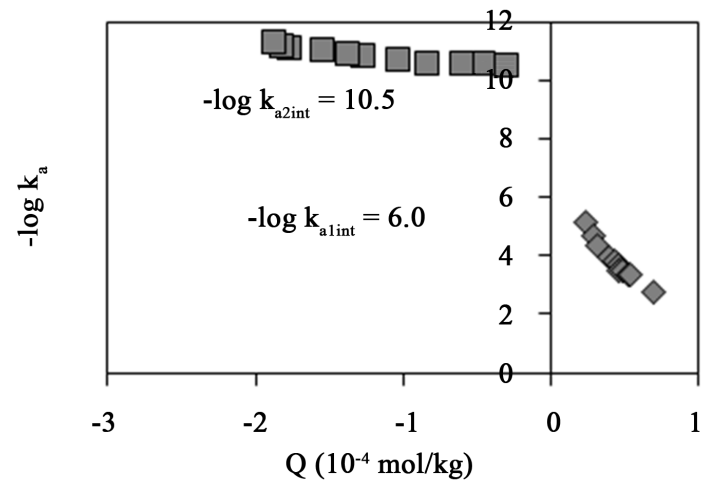

(a)

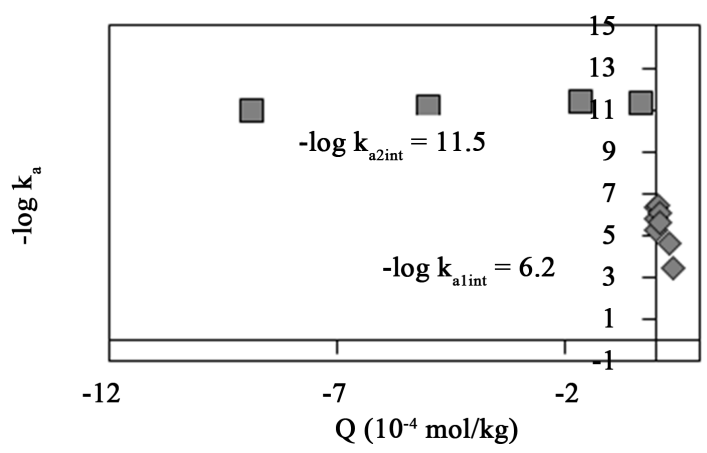

(b)

Figure 3. Conditional deprotonation constants as a function of surface charge for $\mathrm{Na}$-sepiolite and $\mathrm{Na}$-palygorskite suspended in $0.1 \mathrm{M} \mathrm{NaNO}_{3}$. Intrinsic constants are informed. (a) Na-sepiolite; (b) Na-palygorskite. 
Table 2. Deprotonation constants for Na-sepiolite and Na-palygorskite by Stumm and DDLM methods.

\begin{tabular}{ccccccc}
\hline & Method & Na-sepiolite & Na-palygorskite & $\begin{array}{c}\mathrm{SiO}_{2} \\
{[24]}\end{array}$ & $\begin{array}{c}\mathrm{Al}_{2} \mathrm{O}_{3} \\
{[24]}\end{array}$ & $\begin{array}{c}\text { Kaolinite } \\
{[27]}\end{array}$ \\
\hline $\log \mathrm{k}_{\mathrm{alint}}$ & $\mathrm{Stumm}$ & -6.0 & -6.2 & 0.3 & -7.2 & -4.4 \\
$\log \mathrm{k}_{\mathrm{a} 2 \mathrm{int}}$ & -10.5 & -11.5 & -7.2 & -9.5 & -9.2 \\
$1 / 2\left(\mathrm{pk}_{\mathrm{alint}}+\mathrm{pk}_{\mathrm{a} 2 \mathrm{int}}\right)[28][29]$ & 8.3 & 9.0 & 3.5 & 8.5 & 6.8 \\
$\log \mathrm{k}_{\mathrm{a} 1}$ & -4 & -5 & - & - & - \\
$\log \mathrm{k}_{\mathrm{a} 2}$ & -9.5 & -9.5 & - & - & - \\
$\log \mathrm{k}_{\mathrm{XH}}$ & 1.5 & 1.5 & - & - & - \\
$\log \mathrm{k}_{\mathrm{XNa}}$ & $\mathrm{DDLM}$ & 1 & 3 & - & - & - \\
$\log \mathrm{k}_{\mathrm{X} 2 \mathrm{Mg}}$ & 5 & 5 & - & - & - \\
\hline
\end{tabular}

tain moderately strong-acidity and weak-acidity surface groups, although the values were more similar to those of $\gamma-\mathrm{Al}_{2} \mathrm{O}_{3}$. Sepiolite and palygorskite have abundant $\mathrm{Mg}^{2+}$ in the octahedral layer, and therefore since $\mathrm{Mg}$-OH edge groups are of lower acid character than $\mathrm{Al}-\mathrm{OH}$ groups, the lower $\mathrm{k}_{\mathrm{a} 2 \mathrm{int}}$ constant values are consistent with the presence of $\mathrm{Mg}$-OH groups.

For pure oxides, the magnitude $1 / 2\left(\mathrm{pk}_{\mathrm{alint}}+\mathrm{pk}_{\mathrm{a} 2 \mathrm{int}}\right)$ indicates the point of zero net proton charge (znpc), but for fibrous clay minerals like sepiolite and palygorskite it shows both the acidity of the surface groups and the $\mathrm{pH}$ value towards which aqueous clay suspensions tends. The calculated $1 / 2\left(\mathrm{pk}_{\mathrm{alint}}+\mathrm{pk}_{\mathrm{azint}}\right)$ values for both clay minerals reflect the composition of sepiolite and palygorskite showing the influence of the different constituents: $\mathrm{SiO}_{2}(\mathrm{znpc}=3.5), \mathrm{MgO}$ $(\mathrm{znpc}=12.0)$, and $\gamma-\mathrm{Al}_{2} \mathrm{O}_{3}(\mathrm{znpc}=8.5)$.

In addition, sepiolite and palygorskite have permanent negative charge. This charge is found diffused throughout the structure causing a negative electric field and this fact could be another cause for the observed lower acidity on the edge groups.

\subsection{Deprotonation Equilibria Analyzed through the Surface Speciation Using MINTEQ Program with DDLM}

The comparison of the intrinsic constants calculated by Stumm method and those obtained by MINTEQ (Table 2) shows little agreement between them. This distinctive feature can be related with the limitations of both theoretical methods. In Stumm method, the constants $\mathrm{k}_{\mathrm{alint}}$ and $\mathrm{k}_{\mathrm{a} 2 \mathrm{nt}}$ involve all the acid-base reactions while in DDLM the constants are unfold in a set of various constants

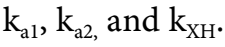

Figure 4 (Na-sepiolite) and Figure 5 (Na-palygorskite) show the fitting between the $\mathrm{H}^{+}$adsorption experimental points and the theoretical curve calculated using Equations (1)-(4), considering the DDLM. Surface species distribution (at $\mathrm{I}=0.1$ ) as a function of $\mathrm{pH}$ is displayed too. 


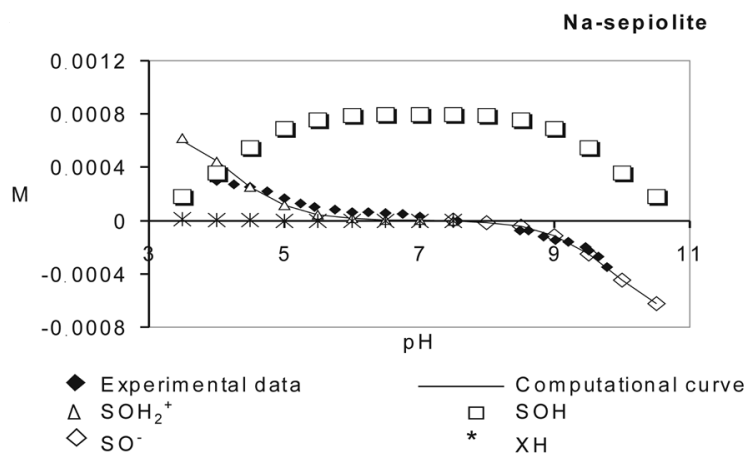

Figure 4. Computed adsorption of $\mathrm{H}^{+}$and $\mathrm{OH}^{-}$and distribution of surface species for Na-sepiolite at $\mathrm{I}=0.1$.

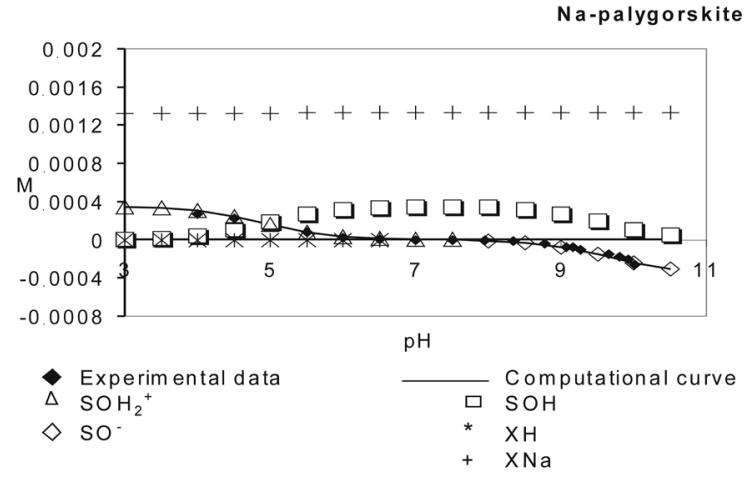

Figure 5. Computed adsorption of $\mathrm{H}^{+}$and $\mathrm{OH}^{-}$and distribution of surface species for Na-palygorskite at $\mathrm{I}=0.1$.

The surface sites $\mathrm{SOH}_{2}{ }^{+}$decrease as $\mathrm{pH}$ increases for both clay minerals. The surface sites $\mathrm{SO}^{-}$increase as $\mathrm{pH}$ increases (this behavior can be observed from 8 - $9 \mathrm{pH}$ units). The $\mathrm{SOH}$ groups initially increase (after $\mathrm{SOH}_{2}{ }^{+}$deprotonation) then, a plateau with a slight decrease at $\mathrm{pH}$ higher than 8 or 9 is observed. The decrease is due to the formation of $\mathrm{SO}^{-}$sites.

The permanent charge sites are usually found as $\mathrm{XNa}$ at $\mathrm{I}=0.1$ as can be seen in Figure 5. At low ionic strength $(I=0.002)$, for both clay minerals (Figures are not show), the sites are sodium-free and occupied by $\mathrm{Mg}^{2+}$ but at very low concentration $\left(\mathrm{X}_{2} \mathrm{Mg}=1.6 \times 10^{-6}\right)$.

According to the DDLM, $\mathrm{H}^{+}, \mathrm{OH}^{-}$and $\mathrm{Na}^{+}$ions are considered adsorbed in the surface plane, as inner-sphere complexes. This is accepted by the traditional theory for the first two ones (usually known as potential determining ions), but not for $\mathrm{Na}^{+}$. The small $\mathrm{Na}^{+}$ion remains as an outer-sphere complex (surrounded by a solvation shell) due to its great hydration energy.

Lately, for the analysis of surface structure of clay minerals, and $\mathrm{H}^{+}, \mathrm{OH}^{-}$, and some cations adsorption new computer treatments (Monte Carlo simulation and Molecular Dynamics [30]) have been applied. The aim is to reproduce the thermodynamic equilibrium properties of a system in which the particles interact through potential energy functions. One of the most interesting aspects that have been studied in this context is the site type in which $\mathrm{Na}^{+}$is adsorbed on the surface. Molecular Dynamic Model treatment [31] would indicate that $\mathrm{Na}^{+}$is 
adsorbed on the edges as inner sphere complexes.

\section{Conclusions}

Intrinsic constants of deprotonation were calculated by two different ways:

1) Stumm method, by extrapolating to zero the function that relates $Q$ with the logarithms of apparent acidity constants.

2) Using MINTEQ program by minimizing the differences between surface $\left[\mathrm{H}^{+}\right]$data and the values calculated from deprotonation constants proposed according to DDLM.

The calculated values for $\mathrm{k}_{\text {aint }}$ constants of these clay minerals were intermediate between those for $\mathrm{SiO}_{2}$ and $\gamma-\mathrm{Al}_{2} \mathrm{O}_{3}$ being in agreement with minerals that contain moderately strong-acidity and weak-acidity surface groups, although the values were more similar to those of $\gamma-\mathrm{Al}_{2} \mathrm{O}_{3}$.

The comparison of the intrinsic constants calculated by the Stumm method and those calculated by MINTEQ program showed little coincidence between them.

Experimental values were in agreement with data from MINTEQ program. In surface species distribution, $\mathrm{SOH}_{2}{ }^{+}$surface sites decreased as $\mathrm{pH}$ increased, $\mathrm{SOH}$ groups (usually considered the reactive sites to cation complexation) initially increased forming a plateau with a slight decrease $(\mathrm{pH} 8-9)$ due to the formation of $\mathrm{SO}^{-}$sites. $\mathrm{X}^{-}$sites (permanent negative charge) resulting from isomorphic substitutions or vacancies in the mineral structure adsorbed $\mathrm{H}^{+}, \mathrm{Na}^{+}$or $\mathrm{Mg}^{2+}$ ions.

\section{Acknowledgements}

The authors thank Secretaría de Ciencia y Tecnología de la Universidad Nacional del Sur, Bahía Blanca, Argentina (Project: 24/Q051) for the financial support.

\section{References}

[1] Brindley, G.W. and Pedro, G. (1972) Report of the AIPEA Nomenclature Committee. AIPEA Newsletter, 4, 3-4.

[2] Bradley, W.F. (1940) The Structural Scheme of Attapulgite. American Mineralogist, 25, 405-410.

[3] Brauner, K. and Preisinger, A. (1956) Struktur und Enstehund des Sepioliths. Tschermaks Mineralogische und Petrographische Mitteilungen, 6,120-140. https://doi.org/10.1007/BF01128033

[4] Jones, B.F. and Galán, E. (1988) Sepiolite and Palygorskite. In: Bailey, S.W., Ed., Reviews in Mineralogy. Hydrous Phyllosilicates, Vol. 19, Mineralogical Society of America, Michigan, 631-674.

[5] Singer, A. (2002) Palygorskite and Sepiolite. In: Dixon, J.B. and Schulze, D.G., Eds., Soil Mineralogy with Environmental Applications, Soil Science Society of America, 555-583.

[6] Singer, A. (1989) Palygorskite and Sepiolite Group Minerals. In: Dixon, J.B. and Weed, S.B., Eds., Minerals in Soil Environment, Soil Science Society of America, 
829-872.

[7] Cao, E., Bryant, R. and Williams, D.J.A. (1996) Electrochemical Properties of NaAttapulgite. Journal of Colloid and Interface Science, 179, 143-150. https://doi.org/10.1006/jcis.1996.0196

[8] Lu, W. and Smith, E.H. (1996) Modelling potentiometric titration behavior of glauconite. Geochimica et Cosmochimica Acta, 60, 3363-3373.

[9] Bradbury, M.H. and Baeyens, B. (1997) A Mechanistic Description of Ni and Zn Sorption on Na-Montmorillonite. Part II: Modelling. Journal of Contaminant Hydrology, 27, 223-248.

[10] Baeyens, B. and Bradbury, M.H. (1997) A Mechanistic Description of Ni and Zn Sorption on Na-Montmorillonite. Part I: Titration and Sorption Measurements. Journal of Contaminant Hydrology, 27, 199-222.

[11] Baeyens, B. and Bradbury, M.H. (2005) Experimental Measurements and Modeling of Sorption Competition on Montmorillonite. Geochimica et Cosmochimica Acta, 69, 4187-4197.

[12] Spathariotis, E. and Kallianou, C. (2001) Adsorption of Copper, Zinc, and Cadmium on Clay Fraction of Two Acid Soils: Surface Complexation Modeling. Communications in Soil Science and Plant Analysis, 32, 3185-3205. https://doi.org/10.1081/CSS-120001115

[13] Duc, M., Gaboriaud, F. and Thomas, F. (2005) Sensitivity of the Acid-Base Properties of Clays to the Methods of Preparation and Measurement: 1. Literature Review. Journal of Colloid and Interface Science, 289, 139-147.

[14] Duc, M., Gaboriaud, F. and Thomas, F. (2005) Sensitivity of the Acid-Base Properties of Clays to the Methods of Preparation and Measurement: 2. Evidence from Continuous Potentiometric Titrations. Journal of Colloid and Interface Science, 289, 148-156.

[15] Arda, D., Hizal, J. and Apak, R. (2006) Surface Complexation Modeling of Uranyl Adsorption onto Kaolinite Based Clay Minerals Using FITEQL 3.2. Radiochimica Acta, 94, 835-844. https://doi.org/10.1524/ract.2006.94.12.835

[16] Bourg, I.C., Sposito, G. and Bourg, A.C.M. (2007) Modeling the Acid-Base Surface Chemistry of Montmorillonite. Journal of Colloid and Interface Science, 312, 297 310.

[17] Gaskova, O.L. and Bukaty, M.B. (2008) Sorption of Different Cations onto Clay Minerals: Modelling Approach with Ion Exchange and Surface Complexation. Physics and Chemistry of the Earth, 33, 1050-1055.

[18] Serrano, S., O’Day, P.G., Vlassopoulos, D., García-González, M.T. and Garrido, F. (2009) A Surface Complexation and Ion Exchange Model of Pb and Cd Competitive Sorption on Natural Soils. Geochimica et Cosmochimica Acta, 73, 543-558.

[19] Malamis, S. and Katsou, E. (2013) A Review on Zinc and Nickel Adsorption on Natural and Modified Zeolite, Bentonite and Vermiculite: Examination of Process Parameters, Kinetics and Isotherms. Journal of Hazardous Materials, 252-253, 428 461.

[20] Carter, D.L., Heilman, M.C. and González, C.L. (1965) Ethylene Glycol Monoethyl Ether for Determining Surface Area of Silicate Minerals. Soil Science, 100, 356-360. https://doi.org/10.1097/00010694-196511000-00011

[21] Sumner, M.E. and Miller, W.P. (1996) Methods of Soil Analysis. Part 3. Chemical Methods. In: Spark, D.L., Ed., Cation Exchange Capacity, and Exchange Coefficients, Soil Science Society of America and American Society of Agronomy, Madison, 65-94. 
[22] Hossner, L.R. (1996) Methods of Soil Analysis. Part 3. Chemical Methods. In: Spark, D.L., Ed., Dissolution for Total Elemental Analysis, Soil Science Society of America and American Society of Agronomy, Madison, 49-64.

[23] Charlet, L., Schindler, P.W., Spadini, L., Furrer, G. and Zysset, M. (1993) Cation Adsorption on Oxides and Clays: The Aluminum Case. Aquatic Science, 55, 291 303. https://doi.org/10.1007/BF00877274

[24] Stumm, W., Hohl, H. and Dalang, F. (1976) Interaction of Metal Ions with Hydrous Oxide Surfaces. Croatica Chemica Acta, 48, 491-504.

[25] Gustafsson, J.P. (2004) Visual MINTEQ ver. 2.30, KTH. Royal Institute of Technology, Sweden.

[26] Vico, L.I. and Acebal, S.G. (2008) Adsorption of Manganese (II) from Aqueous Solutions by Na-Sepiolite and Na-Palygorskite. Agrochimica, 52, 209-225.

[27] Schindler, P.W., Lietchti, P. and Westall, J.C. (1987) Adsorption of Copper, Cadmium and Lead from Aqueous Solution to the Kaolinite/Water Interface. Netherlands Journal of Agricultural Science, 35, 231-240.

[28] Parker, J.C., Zelazny, L.W., Sampath, S. and Harrris, W.G. (1979) A Critical Evaluation of the Extension of Zero Point of Charge (ZPC) Theory to Soil Systems. Soil Science Society America Journal, 43, 668-674. https://doi.org/10.2136/sssaj1979.03615995004300040008x

[29] Sposito, G. (1981) The Operational Definition of the Zero Point of Charge in Soils. Soil Science Society America Journal, 45, 292-297. https://doi.org/10.2136/sssaj1981.03615995004500020013x

[30] Skipper, N.T. (2003) Molecular Modeling of Clays and Mineral Surfaces. CMS Workshop Lectures Vol. 12.

[31] Cygan, R.T. (2003) Molecular Modeling of Clays and Mineral Surfaces. CMS Workshop Lectures Vol. 12.

\section{Submit or recommend next manuscript to SCIRP and we will provide best service for you:}

Accepting pre-submission inquiries through Email, Facebook, LinkedIn, Twitter, etc. A wide selection of journals (inclusive of 9 subjects, more than 200 journals)

Providing 24-hour high-quality service

User-friendly online submission system

Fair and swift peer-review system

Efficient typesetting and proofreading procedure

Display of the result of downloads and visits, as well as the number of cited articles

Maximum dissemination of your research work

Submit your manuscript at: http://papersubmission.scirp.org/

Or contact nr@scirp.org 